Ann. Génét. Sél. anim., I980, 12 (2), I43-I55.

\title{
Effects of the $m$ gene for muscular hypertrophy on conformation at one year of age in beef cattle
}

\author{
C. F. G. NOTT' ${ }^{1}$, W. C. ROLLINS and MOIRA TANAKA \\ Department of Animal Science, \\ University of California, Davis, CA 956r6, U.S.A.
}

\section{Summary}

Ninety-five calves, mostly Angus, but also of Hereford and Shorthorn breeding, born in the University of California herd, were studied, including 54, born during Spring 1970, genotypically distributed as $7 \mathrm{~mm}, 33 \mathrm{~m}+$ and $\mathrm{I} 4++(\mathrm{m}$ being the symbol for the autosomal allele for doublemuscling).

Conformation was evaluated at yearling age by scoring superficial muscles for bulginess and the lateral shape of the rump, and combining the scores into an index $\left(I_{2}\right)$. Differences between $m m$ and $m+$ and between $m+$ and ++ , were significant $(\mathrm{P}<0.00 \mathrm{r})$. Comparing $m+$ with ++ , the expression of the $m$ gene was enhanced in bulls; the interaction between genotype and sex was significant $(\mathrm{P}<0.005)$.

The phenotypic variance of heterozygotes $(m+)$ exceeded that of normals $(++)$ for $\mathrm{I}_{2}(\mathrm{P}<0.05)$ and 365 -day liveweight $(\mathrm{P}<0.05)$, height at withers $(0 . \mathrm{I}<\mathrm{P}<0.25)$ and cannon bone (metacarpus) circumference $(\mathrm{P}>0.25)$.

For each of these four traits, $|\overline{m m}-\overline{m+}|$, the absolute difference between means, was more than twice as great as $|\overline{m+}-\overline{++}|$.

The effect of the $m$ gene in the heterozygote on the mean and standard deviation, was greater for muscle conformation $\left(\mathrm{I}_{2}\right)$ and liveweight than for skeletal traits. The difference appeared to be related to the selection history of beef cattle and to the magnitude of the effect of the $m$ gene in the homozygote $(\mathrm{mm})$.

A monohybrid autosomal mode of inheritance for double-muscling is supported by these results. They indicate also that current commercial selection standards for beef cattle are likely to unconsciously favour the heterozygote $(m+)$ compared with normal $(++)$.

\section{Index terms}

Muscular hypertrophy, double muscling, beef cattle, body conformation

I. Wickham Hall, Halstead, Essex $\mathrm{CO}_{9} 2 \mathrm{PH}$, Eingland. 


\section{Introduction}

This paper reports differences in body conformation for double-muscled $(\mathrm{mm})$, heterozygous $(m+)$ and normal $(++)$ beef cattle at one year of age. Comparisons between the phenotypic means and variances associated with the three genotypes are presented.

Beef cattle manifesting the genetic condition of double-muscling (muscular hypertrophy) are characterized by extraordinarily bulging muscles of the shoulder and thigh, a very rounded rear end (lateral aspect), and a fine-boned skeleton; the enlarged muscles and reduced subcutaneous fat give the intermuscular grooves particular prominence. Double-muscled cattle have a greater proportion of muscle in the body, less bone and viscera and much less fat compared with normal animals. The condition appears to be transmitted according to a monohybrid autosomal mode of inheritance (OLIVER and CARTWRIGHT, I968; RolLINS et al., 1972).

Reviews of the literature on double-muscling have been made by LAUVERGNE et al., (I963, I968); Oliver and CARTWRIGHT (I968); and BoyAJEAN et al. (197r).

\section{Materials and methods}

Effects of the $m$ gene for muscular hypertrophy on body conformation at one year of age were observed mainly in the background of the Aberdeen Angus breed, but also the Hereford and Shorthorn. All three breeds are of a similar size. Rol,INS et al. (I972) described the experimental herd of the University of California at Davis (U.C. Davis).

An animal is classified as double-muscled $(\mathrm{mm})$ or non-double-muscled on the basis of its phenotype. A non-double-muscled animal is classified as $m+$ or ++ on the basis of pedigree or progeny test.

Conformation, interpreted as the fullness or bulginess of muscles and lateral shape of the rump, was measured at yearling age by scoring superficial muscles and rump shape and combining the scores into an index $\left(I_{2}\right)$ (RoLLINs et al., 1972). Liveweight, height at withers and cannon bone (metacarpus) circumference at 365 days of age, were measured also.

Yearling conformation scores $\left(\mathrm{I}_{2}\right)$ were available on 95 calves which were all born at U.C. Davis during I 969 or 1970 . However, estimations of the differences in conformation between genotypes $m m, m+$ and ++ were restricted to the r 970 calves because experimental conditions in that year were more controlled. These calves were genotypically distributed as $7 \mathrm{~mm}, 33 \mathrm{~m}+$ and $\mathrm{I}_{4}++$.

Most of the 1970 calves were born within a $2 \frac{1}{2}$-month period during the Spring of that year, and were weaned at approximately six months of age. After weaning until one year of age calves were fed ad libitum, the roughage : concentrate ratio of the rations being 75:25 and 70:30, for bulls and heifers, respectively.

As sires of the $1970 \mathrm{~mm}$ and $m+$ calves, 644 and 856 were chosen from amongst the several bulls at U.C. Davis who were carrying the $m$ gene, because they were the only double-muscled $(\mathrm{mm})$ Angus bulls available, who were also both unre- 
lated to the cow herd and to each other. Sire 644 was a Red Angus bull, son of a Certified Meat Sire (CMS), and half-brother to a CMS. Sire 856 was an Angus bull, purchased as a double-muscled calf, the offspring of a commercial dam and an unknown sire. As sire of the ++ calves, $A n g u s$ bull Co5 was chosen primarily on the basis of his "normal " appearance, i.e. because there was no suspicion that he was heterozygous. Co5 also had a CMS classification.

No distinction will be made henceforth between Angus and Red Angus since the breeds differ only in colour.

To qualify for the tittle Certified Meat Sire, a minimum of ro progeny of the bull must meet or exceed standards set by Performance Registry International, P.O. Box I33, Joplin, Missouri 6 480I, U.S.A. These standards implicitly include liveweight at 365 days of age.

It was necessary to combine straightbred (AA) and crossbred (XB) data for $m+$ and ++ calves. However, crossbreds are expected to show a greater 365 -day liveweight relative to syraightbreds, and this effect on weight might well carry over to the other yearling traits studied, viz. $I_{2}$, height at withers and cannon (metacarpus) circumference. The effect of genotype $(m+$ or ++$)$ on conformation is confunded with this effect of crossbreeding unless the data are adjusted. Crossbred data were therefore adiusted to a straightbred basis by using adjustment factors derived from the difference between means $(\mathrm{XB}-\mathrm{AA})$ within genotype, and the ratio of phenotypic standard deviations $\left(\hat{\sigma}_{m+} / \hat{\sigma}_{++}\right)$for each trait.

TABLE I

Frequency distribution for conformation at yearling age $\left(I_{2}\right)$

Distributions des fréquences de la conformation a un an $\left(I_{2}\right)$

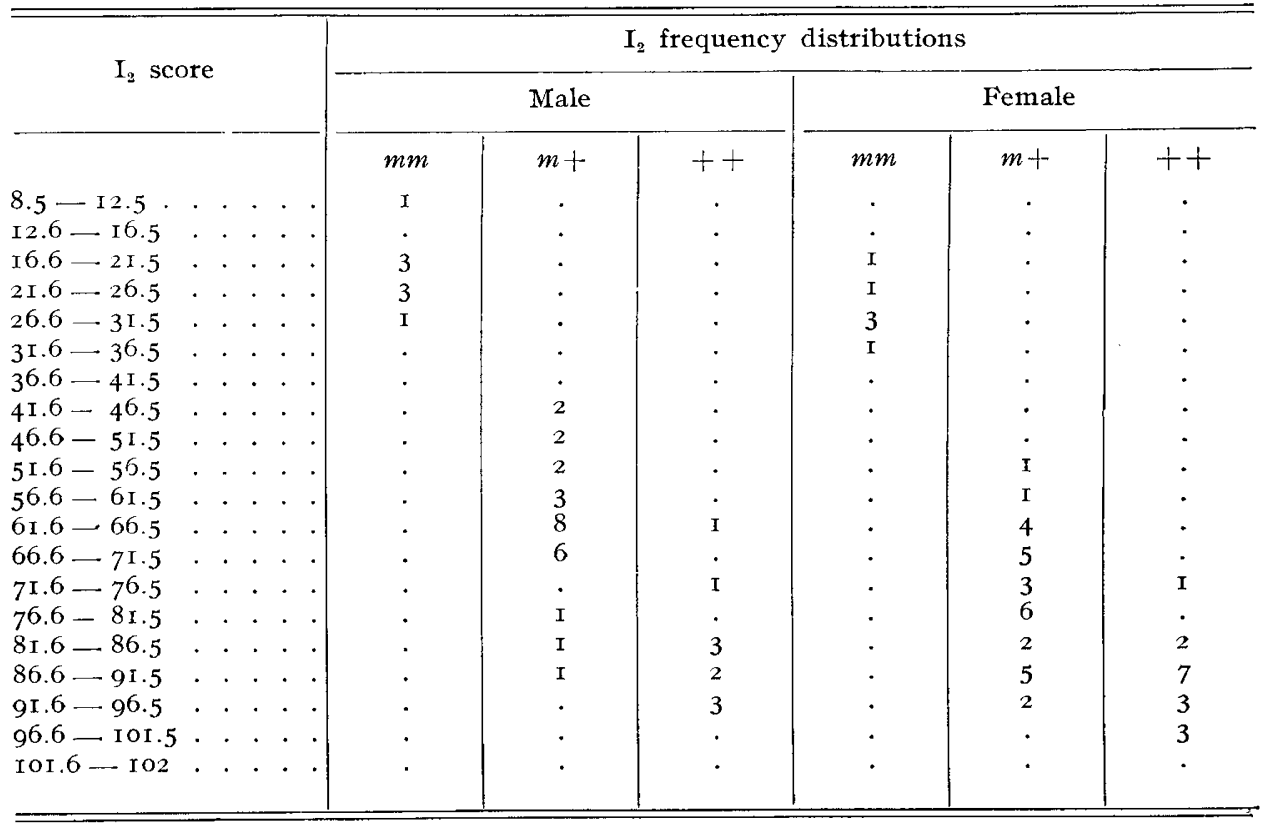




\section{Results}

The distributions of the index of yearling conformation $\left(\mathrm{I}_{2}\right)$ for $m m, m+$ and ++ calves are shown in Table $\mathrm{I}$.

The clear separation of $m m$ and $m+$ distributions indicates distinct differences in conformation. The modal values for the $m+$ and ++ distributions are different, although the distributions overlap in both sexes, the overlap being greaterin heifers than in bulls.

For each genotype there is variation in expression of conformation (muscularity) around the modal value, the variation being greater in $m+$ than in ++ or $m m$.

The trincodal nature of the distributions of $\mathrm{I}_{2}$ provides evidence for the monohybrid autosomal mode of inheritance of the $m$ gene for double-muscling. This has been discussed by Rol,LINs et al. (I972). The trait $I_{2}$ clearly reflects genetic influence on conformation.

These genotypic differences in conformation and expressivity of doublemuscling will now be examined in detail in order to explore their causes and validity.

\section{I. - Comparison of means of $I_{2}$}

$\mathrm{I}_{2}$ phenotypic means are given for the three genotypes in Table 2 and the analyses of variance for the comparisons between $m m$ and $m+$ and between $m+$ and ++ are given in Table 3 .

Homozygote $(\mathrm{mm})$ calves had a significantly $(\mathrm{P}<0.00 \mathrm{I})$ lower $\mathrm{I}_{2}$ score than $m+$ (a lower $\mathrm{I}_{2}$ score indicates more muscling). Bulls had more bulging muscles than heifers $(\mathrm{P}<0.025)$ although there was no evidence of an interaction between genotype ans sex.

Heterozygote $(m+)$ calves had a significantly $(\mathrm{P}<0.00 \mathrm{I})$ lower $\mathrm{I}_{2}$ score than ++ , and bulls had more bulging muscles than heifers $(P<0.0 I)$. The interaction between genotype and sex was significant $(\mathrm{P}<0.005)$, évidence that the expression of the $m$ gene was increased in bulls. Since normal $(++)$ bulls tend to show greater muscle development than eifers, the genetic background of heterozygous $(m+)$ bulls may enhance the effect of the $m$ gene.

\section{2. - Comparison of $I_{2}$ with other measures of yearling conformation}

In the double-muscled $(\mathrm{mm})$ animal, the $m$ gene manifests pleiotropic effects, including increasing the fullness (bulginess) of the musculature and depressing 365-day liveweight, height at withers and cannon (metacarpus) circumference (Table 2). The effect of the $m m$ phenotype compared with normal, $(m m-++)$ $\times$ IOO $/(++)$, is more marked for $I_{2}$ and cannon circumference than for the other traits.

The $m+$ phenotype, compared with ++ , shows adistinctly $(\mathrm{P}<0.00 \mathrm{I})$ more bulging conformation of the musculature (Table 2). However, contrary to the effect of the $m m$ genotype, the $m+$ compared with ++ shows a slightly 
TABLE 2

Phenotypic means of yearling traits

Moyennes phenotypiques des caractères du bovin d'un an

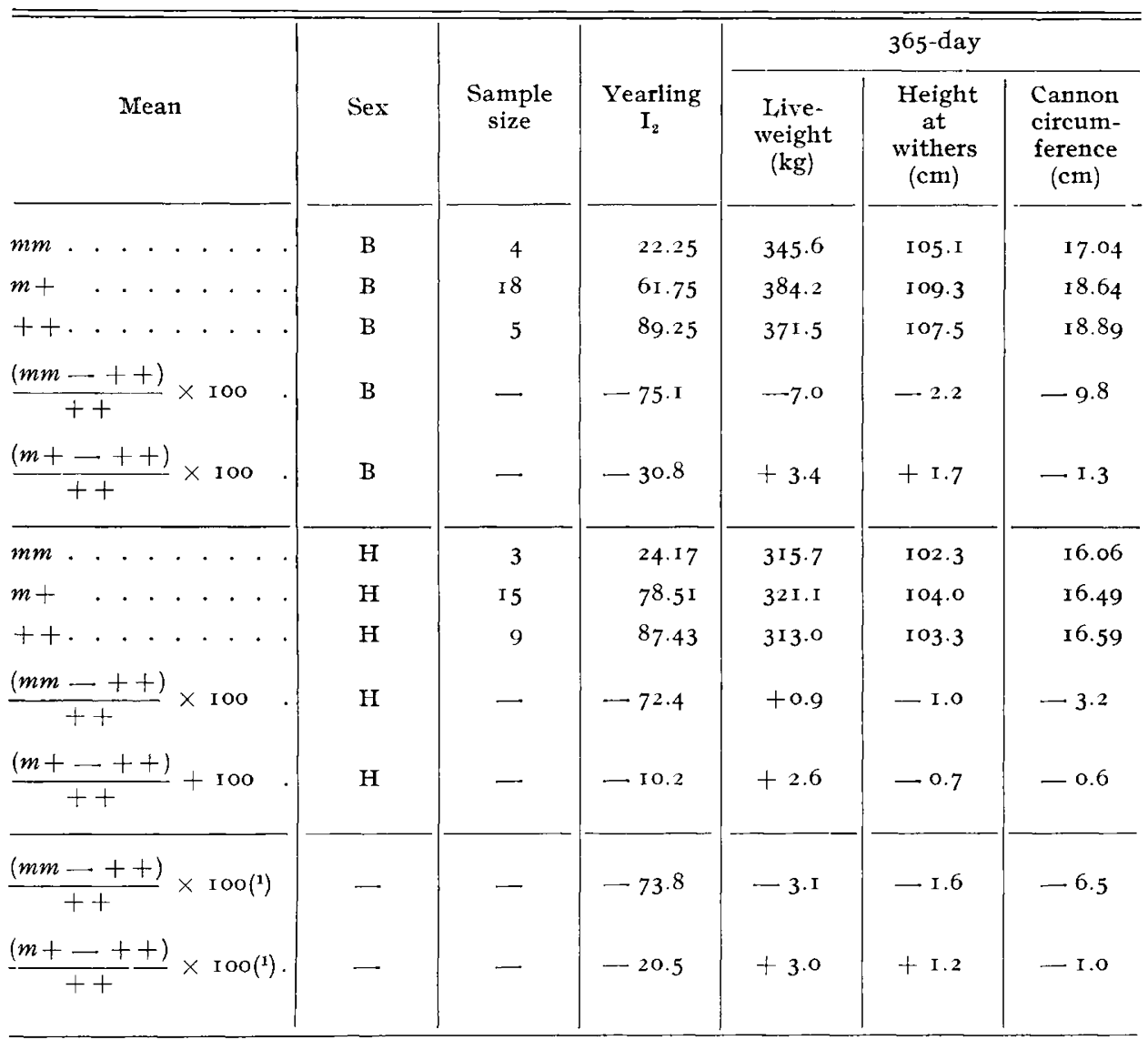

(I) Unweighted averages of Bull and Heifer differences.

TABLE 3

Conformation at yearling age $\left(I_{2}\right):$ Analysis of variance for the comparison of phenotypic means La conformation a un an $\left(I_{2}\right)$ : analyse de la variance pour la comparaison des moyennes phénotypiques

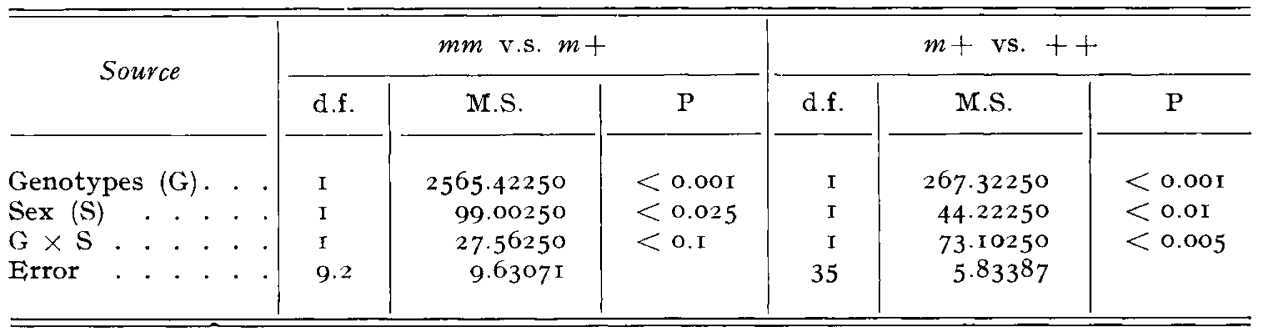


$(\mathrm{P}>0.4)$ increased liveweight and slightly increased height at withers $(\mathrm{P}>0.2)$. The effect on cannon circumference is in the same negative direction as the effect of $m m$, but much reduced in amount $(P>0.1)$.

\section{3. - Comparison of phenotypic variances of $I_{2}$ and other measures of yearling conformation}

Estimates of phenotypic variances for the four yearling traits are presented in Table 4. Estimates of variances for $m m$ calves were made on a within-sex, within straightbred/crossbred status basis because of the small size of progeny groups, i.e. they were not made on a within-sire basis. This method of estimiation should be borne in mind when comparing the variances of double-muscled calves with that of non-double muscled calves because of sire effects.

\section{TABLE 4}

Effects of the $m$ gene on phenotypic variances, standard deviations and means of yearling traits (Effets $d u$ gène $m$ sur les variances phénotypiques, les écarts-types et les moyennes phénotypiques des caractères $d u$ bovin d'un an)

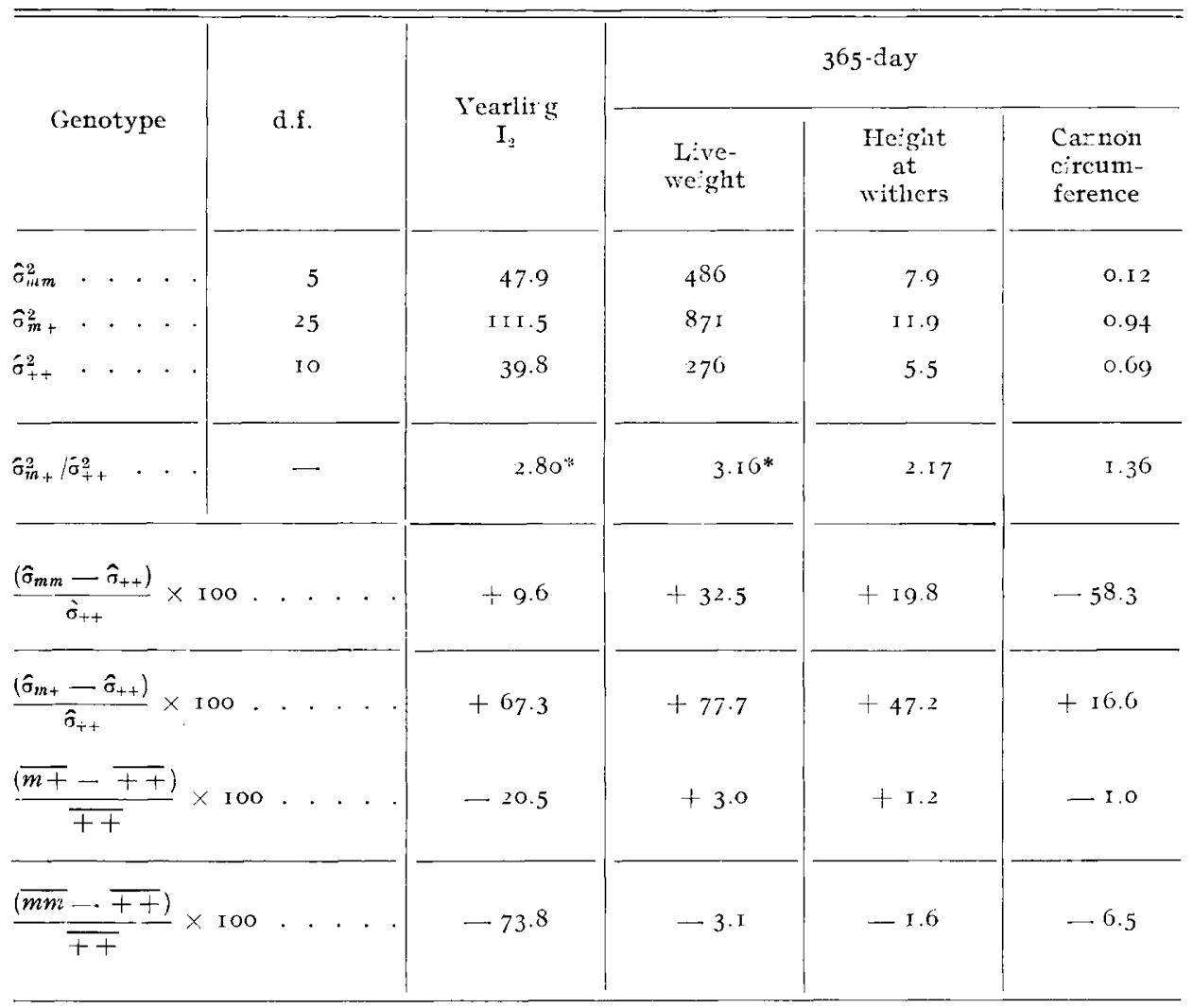

(*) $\mathrm{P}<0.05$. 
The phenotypic variance of heterozygotes $(m+-)$ exceeded that of normals $(++)$ for $\mathrm{I}_{2}(\mathrm{P}<0.05), 365$-day liveweight $(\mathrm{P}<0.05)$, height at withers $(0.1<\mathrm{P}$ $<0.25)$ and cannon bone (metacarpus) circumierence $(P>0.45)$. The effect was more in $l_{2}$ and liveweight and less in skeletal traits.

\section{4. - Comparison of the effect of the $m$ gene on the mean and standard deviation of yearling conformation}

If the effect of the $m$ gene is to change the mean for a trait, compared with the normal mean $(++)$, then the extent of that change may be reflected in the change of variance, or, on a linear scale, in the change of standard deviation. In table 4 the four yearling traits are compared with respect to the effect of the $m$ gene on the mean and the standard deviation and the relationship between them.

Averaging over both sexes for $(\overline{m m}-\overline{++}) \times 100 /(\overline{++})$, the expression of the $m m$ genotype shows most in $\mathrm{I}_{2}$ and cannon circumference, then liveweight and least effect on height at withers. In all traits $\overline{\mathrm{mm}}$ was reduced nemerically, relative to $\overline{f+}$.

The expression of the $m+$ genotype compared with normal, $(\overline{m+}-\overline{+}+)$ $\times$ I00 $/(\overline{++})$, averaged over both sexes, is greatest for $I_{2}$. The mean 365 -day liveweight of heterozygotes was increased $+3 \mathrm{p}$. cent with a corresponding, but smaller, increase in height at withers. The cannon circumference was least affected, but it was reduced - I p. cent.

The increase in $\overline{m+}$ relative to $\overline{++}$ is related to the increase in $\hat{\sigma}_{m+}$ relative to $\hat{\sigma}_{++}$Using the statistics $(\overline{m+}-\overline{++}) \times 100 /(\overline{F+})$ and $\left(\hat{\sigma}_{m+}-\hat{\sigma}_{++}\right)$ $\times$ IOO $/\left(\hat{\sigma}_{++}\right)$, the effect of heterozygosity is expressed more on traits $I_{2}$ and liveweight and less on traits height at withers and cannon circumference.

\section{Discussion}

This study demonstrated that it was possible to treat bovine conformation at one year of age as a quantitative genetic trait. The trimodal distribution of the index of conformation $\left(I_{2}\right)$ provided evidence for the monohybrid autosomal mode of inheritance of the double-muscled condition. It was thereby possible to observe the effect of the mutant $m$ gene on conformation at yearling age.

The expression of the homozygote $(\mathrm{mm})$ genotype showed more in $\mathrm{I}_{2}$ and cannon circumference and less in 365-day liveweight and height at withers (Table 2). The $m m$ calves were heavier $(+7$ p. cent) than ++ calves at 180 days (weaning) but their post-weaning growth rate was markedly depressed (- I7 p. cent) due to a reduced ( - II p. cent) feed intake, compared with non- $m m$ controls (NoTT and RoLLINS, I979). The genetic potential for post-weaning growth is greater for double-muscled than for non-double-muscled animals (RAImond, I96I; Neuvy and Vissac, I962; Hanset and Demoulin, I965; ANonymous, I966; FAliez, I966; Trillat (I967) cited by Boyajean et al., I97I). Thus, in a favourable environment, where the diet contains a high enough proportion of concentrates, the expression of $m$ in the homozygote is towards increasing liveweight at 365 days. 
On the development of the long bones of the skeleton, the $m$ gene in the homozygote $(\mathrm{mm})$ has more effect on later-developing width than on earlier-developing length, and more effect on later-developing proximal bones (e.g.) humerus than on earlier-developing distal bones (e.g. metacarpus) (VISSAC, I968; RoLLINS et al., I969; HANSET and ANSAY, I972). The opposite is true for the $d$ gene for Snorter dwarfism in cattle. This pattern of effect of the $m$ gene, together with the lower yearling liveweight of $\mathrm{mm}$ compared with ++ , explains, in part, the observation of less effect of $m m$ on height at withers and more effect on cannon circumference.

For each of the four traits measuring conformation, $|\overline{m m}-\overline{+}|$, the absolute difference between the homozygote $(\mathrm{mm})$ and heterozygote $(m+)$ means, was more than twice as great as $|\overline{m+}-\overline{++}|$, the absolute difference between the heterozygote $(m+)$ and normal $(++)$ means. However, the $m$ gene in the heterozygotes $(m+)$ had a greater effect on the mean for conformation of muscling $\left(I_{2}\right)$ and 365 -day liveweight than on skeletal characters $(365$-day height at withers and cannon circumference), i.e. the partial dominance (incomplete recessiveness of the $m$ gene was greater in traits reflecting muscle growth than in those measuring bone growth.

The action of the $m$ gene in the heterozygous condition may be different from its action in the homozygote, at least because of the incompletely dominant allele $(+)$. However, the expression of the $m$ gene, both in the heterozygote and in the homozygote, probably depends upon background modifying genes (genes of individually small effect) besides the environment. A consideration of the background modifying genes provides a possible explanation as to why the $m$ gene in the heterozygote has a greater effect on $\mathrm{I}_{2}$ and liveweight, both of which reflect muscle growth, and less effect on height at withers an cannon circumference, both measures of skeletal growth.

The expression of a mutant gene in homozygotes and heterozygotes, and the dominance relations between two alleles, can be modified by selection (CASTLE and Philil,ps, I9I4; Wright and Chase, I936; Ford, I940; Fisher and Holt, I944). Thus it would be expected that the $m$ gene would have a greater effect on the mean in the heterozygote $(m+)$ for traits in which selection criteria had been in the same direction as the effect of the $m$ gene, and less effect where selection had been in the opposite direction. This expectation is realised when the magnitude of the different effects of the $m$ gene on the four yearling traits are compared (Table 2).

In this experiment, the $m$ gene in heterozygous condition was studied in the background of the British beef breeds which have been selected primarily on growth rate and carcass characteristics; reflecting weight gain and muscle development, with much less emphasis on the skeleton. Since selection for weight and muscle development in beef cattle and the expression of the $m$ gene are both in the same direction, the background modifying genes may enhance the expression of the $m$ gene in heterozygous condition for muscle conformation $\left(I_{2}\right)$ and 365 -day liveweight. Bulls generally have muscles which are more bulging than heifers, and thus for similar polygenic reasons the effect of the $m$ gene on the mean for yearling conformation $\left(\mathrm{I}_{2}\right)$ of heterozygotes was greater in bulls than in heifers.

In recent years, beef cattle selection has emphasized larger mature size (size of frame at yearling age which is related to height at withers), longer legs and heavier bone (thicker cannon bones) (AMER. ANGus Assoc., I965; ELINGs et al., I969; LoNG, I97I). The $m$ gene, in the homozygote $(m m)$, depresses height at 
withers and reduces cannon circumference. Since the selection for skeletal characters in beef cattle and the expression of the $m$ gene are both in opposite directions, the background modifiers may attenuate the expression of the $m$ gene in heterozygous condition for 365-day height at withers and cannon circumference. Nevertheless, despite the slightly increased mean liveweight, the effect of $m$ un heterozygotes was to reduce cannon circumference, an effect in the same negative direction as the effect of $m$ in homozygotes $(\mathrm{mm})$.

Evidence from the literature indicates that the more bulging conformation of the double-muscled $(\mathrm{mm})$ compared with non-double-muscled animals can be explained, in part, by a generalized but not uniform muscular hypertrophy together with a shortening of the long bones (BUTTERFIELI, I966; VISSAC, I968; ROLLINS et al., I969; VISSAC et al., I97I; HANSET and ANSAY, 1972). The heterozygote $(m+)$ showed distinctly $(\mathrm{P}<0.00 \mathrm{I})$ more bulging conformation of the musculature $\left(I_{2}\right)$ compared with normal $(t+)$, which might be due to a similar hypertrophy of the musculature, with gradients of muscular hypertrophy in parts of the body, in the same direction as the expression in the double-muscled $(\mathrm{mm})$ animal but much reduced in amount. The corresponding superiority of the $m+$ animals for carcass traits, compared with ++ , was discussed by THIESSEN (I973).

For the overall trait of double-muscling, it appears that in the Italian Piedmont breed the average phenotype of the heterozygote $(m+)$ lies closer to the doublemuscled $(\mathrm{mm})$ phenotype, whereas in the major British breeds, e.g. Angus, the heterozygote lies closer to the normal $(++)$ phenotype. One possible interpretation of the difference can be given in terms of the evolution of dominance; thus in the Piedmont breed, where double-muscling is selected for, the $m$ gene would tend to become dominant, but in breeds where it was selected against, the $m$ gene would tend to become recessive (LAUVERGNE et al., I963).

That the phenotypic variance of a major gene influencing a quantitative trait can very depending upon the background modifying genes, was shown by WRIGH'T and CHASE (I936). Their results lead to two expectations : first, that in a genetic background favouring muscle development, the variation in expression of the $m$ gene un heterozygous condition would be large for conformation of the musculature $\left(I_{2}\right)$ and for 365 -day liveweight, and that it would be greater than the variation for normal $(++)$; second, that in an intermediate genetic background, i.e. some modifiers encouraging skeletal growth, other modifiers discouraging it, the variation in expression of the $m$ gene in heterozygotes would be small for 365-day height at withers and cannon circumference, but that it would also be greater than the variation for normals $(++)$. The variance estimates given in Table 4 show that these two expectations are met.

It is expected, according to one view, that the heterozygote for a mutant gene would be more variable than the wild type (FISHER, 1948; p. 62). Similary, the presence in the genome of a mutant gene can be expected to result in an increase in the phenotypic variance (WADDINGTON, I942; Mrchie, I958). The explanation for this may lie in terms of the evolutionary adaptation of genes. $\mathrm{By}$ replacing a + allele with $m$ in the heterozygote, the genome of that individual is being changed, which allows gene-gene and gene-environment interactions which have not been adapted to one another by selection; thus phenotypic variation is expected to increase.

It can be seen that for all four traits Fisher's rule $\sigma_{m+}^{2}>\sigma_{++}^{2}$, applies (Table 4). The magnitude of the difference between the variance estimates, $\hat{\sigma}_{m+}^{2} / \hat{\sigma}_{++}^{2}$, depends upon the different genetic backgrounds for the different traits, and is 
probably related to the selection history of beef cattle and to the magnitude of the effect of the $m$ gene in the homozygote $(\mathrm{mm})$, already mentioned. The increase in standard deviation $\left(\hat{\sigma}_{m+}-\hat{\sigma}_{++}\right) \times$I0o $/ \hat{\sigma}_{++}$, is related directly, but not in proportion to, the change in the mean, $(\overline{m+}-\overline{++}) \times 100 /(\overline{++})$ (Table 4$)$, which suggests that the modifying genes affecting conformation and weight are different from those affecting the skeleton; this would be expected since muscle and bone are different tissues.

Since, in this study, the $m$ gene behaved as expected, it should be possible to predict the results of deliberately putting the $m$ gene into different genetic backgrounds, which had been selected on the basis of different criteria, for instance meat breeds and dairy breeds. It would be predicted that there would be enhancement of the expression of double-muscling in the meat breed, but attenuation in the dairy breed. The results of crossing double-muscled $(\mathrm{mm})$ and normal $(++)$ Charolais bulls with meat-, rustic- and dairy-breed type females in France (VALLS ORTIZ et al., I972) suggest that the predicted pattern of results may be emerging. The penetrance of the double-muscled character varied in each breed type depending upon whether previous selection had been favourable or unfavourable to muscle development (VISSAC, I972).

There are possible genetic and environmental factors affecting estimates of phenotypic means and variances for $I_{2}$ and the other three traits :

I. As the ++ sire was not mated to nay $m m$ cows, within-sire comparisons of $m+$ and ++ animals cannot be made. To the extent that the sires of the $m+$ and ++ animals were polygenically different, the distributions of $I_{2}$ ave biased by sire effects.

2. The effect of a calf, alleged to be ++ , actually being $m+$, would be one of increasing the overlap between the $m+$ and ++ distributions of $I_{2}$.

3. Crossbred progeny, by numerically smaller $I_{2}$ averages, appeared to hace more bulging muscles and rounder rump shapes than straight-breds, but since crossbreds grew faster to 365 days of age than straightbreds, the effect may be primarily due to differences in weight, rather than to crossbreeding, per se.

4. The $I_{2}$ scores were not adjusted for differences in liveweight. Although the heavier animal might be expected to show greater muscular development, the physiologically older animal would also be expected to be laying down more subcutaneous fat than the younger and lighter animal which would reduce the prominence of the superficial muscles, and the development of the lower round would make the lateral view of the animal look more rectangular or "normal". The consequence of greater physiological age might be to increase the $I_{2}$ score (less apparent bulginess of muscles). So a higher weight does not necessarily mean a lower $\mathrm{I}_{2}$ score (greater apparent bulginess of muscles).

5 . For both bulls and heifers the range of 365 -day weights for ++ animals lay within the range for $m+$ animals, i.e. the lightest and heaviest non-doublemuscled animals were $m+$. The wider range and larger variance for the $m+$ might be due to an interaction between the $m$ gene and the environment, the result depending upon whether the background modifying genes were favourable or unfavourable to growth.

6. In the homozygote $(\mathrm{mm})$, the effect of the $m$ gene on conformation is marked, but double-muscled calves tend to be less viable suggesting that the $m$ gene allows greater susceptibility to environmental stress. In the heterozygote 
$(m+)$, with a + allele to mask the effect of the $m$ gene, the susceptibility may usually, but not always, be less. When the environmental susceptibility is less, the resulting heterozygote $(m+)$ phenotype is a more bulging conformation of the musculature than the normal $(++)$ range. Many of the $m+$ calves expressed such a phenotype. Although the relationship between $I_{2}$ and liveweight is not direct, poorly growing animals would nevertheless be expected to show a rather flat musculature.

\section{Conclusions}

Conformation at one year of age was treated as a quantitative trait and the effect of the $m$ gene on that trait was observed.

With conformation interpreted as the bulginess of superficial muscles and the lateral shape of the rump, combined into an index $\left(I_{2}\right)$, there was a marked $(-73.8$ p. cent) difference between homozygote $(\mathrm{mm})$ and normal $(++)$ animals, and a smaller $(-20.5$ p. cent $)$ but significant $(P<0.00 I)$ difference between heterozygotes $(m+)$ and normals $(++)$ (a lower $\mathrm{I}_{2}$ score indicates more muscling). The effect in $m+$ was greater in bulls than in heifers $(\mathrm{P}<0.005)$.

Comparing $m m$ with ++ , the effect was most evident in increasing muscularity $\left(\mathrm{I}_{2}\right)$ and in reducing cannon bone (metacarpus) circumference ( $-6.5 \mathrm{p}$. cent). Yearling liveweight (-3.I p. cent) and height at withers $(-$ I.6 p. cent) were slightly reduced also.

Comparing $m+$ with ++ , the effect was greater for $\mathrm{I}_{2}$ and liveweight $(+3.0$ p. cent) than for height at withers (+ I.2 p. cent). The effect on cannon circumference ( - I.o p. cent) was in the same negative direction as $m m$ but much reduced in amount. Apart from $\mathrm{I}_{2}$, none of the differences in conformation between $m+$ and ++ was statistically significant, which reflects the role of small sample size and rather large variation, but they may be biologically significant since the expression of the $m$ gene in heterozygous condition was similarly small for other characters studied (NoTT, I973; NotT and Rollins, I979).

For each of the four traits measuring conformation, $\left|\frac{m m}{m m+}-\bar{m}\right|$, the absolute difference between means, was more than twice as great as $|\vec{m}+-\overline{++}|$.

The effect of $m$ on phenotypic variation followed expectations since the phenotypic variance in conformation of heterozygotes $(m+)$ exceeded that of normals $(++)$ for $I_{2}(P<0.05)$, 365-day liveweight $(P<0.05)$, height at withers $(0 . I<P$ $<0.25)$ and cannon circumference $(\mathrm{P}<0.25)$.

The effect of the $m$ gene in the heterozygote $(m+)$ on the mean and standard deviation i.e. the partial dominance (incomplete recessiveness), was greater for muscle conformation $\left(I_{2}\right)$ and liveweight than for skeletal traits. This difference appeared to be related both to the selection history of beef cattle, which has favoured muscle development and weight gain, longer legs and thicker cannon bones, and to the magnitude of the effect of the $m$ gene in the homozygote $(\mathrm{mm})$.

Considered together, the results of this study support the monohybrid autosomal mode of inheritance for double-muscling.

The size of the difference between $m+$ and ++ means for muscularity $\left(I_{2}\right)$ and liveweight at one year of age, and the overlap between $m+$ and ++ distributions for these traits, indicated that current commercial selection standards for beef cattle, which emphasize a bulging musculature in the live animal and heavier weights at younger ages, would unconsciously favour the heterozygote. 


\section{Acknowledgement}

This research was supported in part by the U.S.D.A. (Western Regional Beef Cattle Research) and the American International Charolais Association.

\section{Résumé}

\section{Effets du gène m d'hypertrophie musculaire sur la conformation de bovins de boucherie d'un an}

Quatre-vingt-quinze veaux, principalement de race $A n g u s$ mais aussi Heveford et Shortorn, nés dans le troupeau de l'Université de Californie à Davis ont été étudiés. Des 54 veaux nés au printemps 1970,7 avaient le génotype $m m, 33$ le génotype $m+$ et 14 étaient $++(m$ étant le symbole du gene pour le culard chez les bovins).

Le volume des muscles superficiels et la courbe latérale de la croupe ont été notés. Les notes étaient combinées dans un index $\left(\mathrm{I}_{2}\right)$ pour évaluer la conformation à un an. Les différences entre les génotypes $m m$ et $m+$, et entre $m+$ et ++ étaient significatives $(\mathrm{P}<0.00 \mathrm{r})$. Dans la comparaison entre $m+$ et ++1 'expression du gène $m$ était plus forte chez le mâle; l'interaction entre le génotype et le sexe était signifivatice $(\mathrm{P}<0.005)$.

La variance phénotypique des hétérozygotes $(m+)$ était plus grande que celle des "normaux" $(++)$ pour $\mathrm{I}_{2}(\mathrm{P}<0.05)$, pour le poids vif à 365 jours $(\mathrm{P}<0.95)$, pour la hauteur au garrot $(0, \mathrm{I}<\mathbf{P}<0,25)$ et pour la circonférence de l'os canon (metacarpus) $(\mathrm{P}>0,25)$.

Pour chacun de ces caractères, $|\overline{m m}-\overline{m+}|$, la valeur absolue de la différence entre les moyennes, était plus de deux fois plus grande que $\mid \overline{m+} \cdots \overline{+}+$.

L'effet du gène $m$ chez l'hétérozygote, sur la moyenne et l'écart type, était plus grand pour $I_{2}$ et le poids vif que pour les caractères squelettaux. La différence semblait être liée à l'historique de la sélection des bovins à viande et à l'importance de l'effet du gène $m$ chez les homozygotes $(\mathrm{mm})$.

Ces résultats confirment l'hypothèse de la transmission du caractère culard par un gène autosomal. Ils indiquent aussi que les pratiques actuelles de sélection des bovins de boucherie tendent à favoriser les hérétozygotes $(m+)$ au détriment des "normaux " $(++)$.

\section{Références}

American Angus Association, 1965. Breed Improvement Builds Better Beef. Amer. Angus Assoc., 320 I Frederick Blvd., St-Joseph, Missouri, U.S.A. 48 p.

AnonymoUs, 1966. French reseavch on double muscling in cattle. Edinburgh, 1966. Comm. Anim. Genet., Europ. Assoc. Anim. Prod.

Boyajean Denise, Menissier F., Valis Ortiz J. M., I97I. Document de travail sur le caractère "culard" chez les bovins. Station de Génétique Quantitative et Appliquée, Centre Natn. Rech. Zootech., $7^{8}$ Jouy-en-Josas, France. $3^{8} \mathrm{p}$.

BUTTERFIELD R. M., I966. Muscular hypertrophy of cattle. Austral. Vet. J. 42, 37-39.

Castle W. E., Philips J. C., r9i4. Piebald rats and selection. Carnegie Inst. Wash. Publ. no. 195 .

Elings J. T., Beis F. L., Iyon R. G., I 969 . The modern Beef Steer. University of California Agric. Extension Service AXT - 3I4. November I969, 5M; I3 p.

FALIEZ J., 1966. Étude préliminaire sur le caractère culard dans la race Garonnaise. École Supérieure d'Agriculture de Purpan, Toulouse.

FISHER R. A., I958. The genetical theory of natural secletion. Dover Publ. Inc., New-York. 
Fisher R. A., HolT S. B., I944. The experimental modification of dominance in Danforth's short tailed mutant mice. Ann. Eugen., 12, I02-I20.

FORD E. B., I940. Genetic research in the Lepidoptera. Ann. Eugen. 10, 227-252.

HANSET R., ANSAY M., 1972. Régions privilégiées d'hypertrophie musculaire, chez le bovin culard. Ann. Méd. Vet., 116, I 7-25.

HANSET R., Demoulin J., I965. Une étude comparée de la croissance de trois types de bovins: culard, deux fins et laitier. École de Médecine Vétérinaire de Cureghem, Bruxelles et Centre de Recherches sur l'Élevage et les Productions Fourragères en Haute-Belgique.

Lauvergne, J. J., Vissac B., Perramon A., I963. Étude du caractère culard. I. Mise au point bibliographique. Ann. Zootech. 12, 133-156.

Lauvergne J. J., Boyazoglu J. G., Denise Hubert, r 968 . Le phénomène culard chez les bovins. Bibliographie annotée. Bull. Techn. Dép. Génét. anim. (Inst. natn. Rech. agron., Fr.). No. 2, iv $+49 \mathrm{p}$.

LoNG R., I97I. Ankony Scoring System - Its Uses in Herd Improvement. Better Beef Business. 12 (3), 28-3I; 12 (4), 30-33; 12 (5), 46-47; 12 (6), 3I-32.

MichiE D., I958. The "Background Effect" on phenotypic variability. Proc. X. int. Congr. Genet. I958. 2, I87.

Neuvy A., VISSAC B., I962. Contribution à l'étude du phénomène culard. Union Nationale des Livres Généalogiques. $52 \mathrm{pp}$. Mimeo.

NotT, C.F.G., 1973. The Effects of the m Gene for Muscular Hypertrophy on Body Conformation and Size in Beef Cattle. Ph. D. dissertation. University of California at Davis.

Notr C.F.G., Rol.ins W. C., I979. Effects of the $m$ gene for muscular hypertrophy on bitrhweight and growth to one year of age in beef cattle. Growth, 43, 22 I-234.

Oliver W. M., CarTwrighr T. C., I968. Double muscling in cattle. Departmental Tech. report no. I2, Dept. of Anim. Sci., Texas Agric. Exp. Stat., College Station, Texas. $5^{8}$ p.

RAIMONDI R., I96r. Esperienza comparativa di ingrassamento e di macellazione tra vitelli Piemontesi a "groppa doppia " e communi. Ann. Sper. Agraria. n.s. 15, I05-I5I.

Rolinins W. C., Julian L. M., Carroll F. D., I969. A note on the body composition of a double muscled female and a normal female from a linebred Aberdeen Angus herd. Anim. Prod. 11, III-II4.

Rollins W. C., TANaka Moira, NotT C.F.G., Thifssen R. B., r972. On the mode of inheritance or double muscled conformation in bovines. Hilgardia 41, 433-455.

THIESSEN R. B., I973. Muscular Hypertrophy in Cattle. The Selective Advantage of the Heterozygote $(\mathrm{m}+)$ and the Population Dynamics of the $\mathrm{m}$ Gene. Ph. D. dissertation. University of California Davis.

TrILLAT G., I967. Etude comparative de l'aptitude à la transformation alimentaive de différentes races à viande françaises. Essai d'analyse de la variabilité de la consommation. Mém. fin. Étud., Inst. Tech. Prat. agric., Paris. $3^{8}$ p.

VAlLs ORTiz J. M., Mínissier F., VISSAC B., I972. Étude du caractère culard. VI. Transmission et possibilités d'utilisation en croisement de première génération pour la production de veaux de boucherie. Ann. Génét. Sél. Anim. 4, 7-28.

VISSAC B., I968. Étude du caractère culard. II. Incidence du caractère culard sur la morphologie générale des bovins. Ann. Zootech., 17, 77-ror.

VISSAC B., I972. L'hypertrophie musculaire d'origine génétique ou caractère culard. Ann. Génét. Sél. Anim., 4, 87-97.

VISSAC B., MÉNISSIER F., PERREAU B., I97I. Le caractève culard et son utilisation pratique. Station de Génétique Quantitative et Appliquée, C.N.R.Z., $7^{8}$ Jouy-en-Josas, France.

WAdDINGToN C. H., I942. Canalization of development and the inheritance of acquired characters. Natuve, Lond. 150, 563-565.

WRIGHT S., CHASE H. B., r936. On the genetics of the spotted pattern of the Guinea pig. Genetics 21, $758-787$. 